\title{
FANS CLUBS' VIOLENCE AS AN ENDANGERING FACTOR FOR THE URBAN AREAS' SAFETY
}

\author{
Dragan TRIVAN, PhD \\ Faculty of Business Studies and Law in Belgrade, University Union Nikola Tesla \\ E-mail: dtrivan@gmail.com \\ Slaviša KRSTIC, PhD \\ Faculty of Business Studies and Law in Belgrade, University Union Nikola Tesla
}

\begin{abstract}
Hooliganism and violence, that usually go together with sports events in urban areas, are not happening by accident. They are the reflection of the certain society's state, as well as the reaction to the current or the upcoming state's crisis or the crisis in the state's surroundings. This type of the safety endangerment is worldwide known from the mid twentieth century, after technology and science's development and growth, which made broadcasting of sports events globally available. Also, it made sport very commercialized. In these new circumstances, sport became the tool of different authorities that used media and sport to make stronger impact on their citizens. This is especially characteristic for authoritative regimes. On the other hand, uncontrolled commercializing of sports had for consequence the appearance of different types of extremism and criminal activities, related to sport. Some of those are directly related to fan club's hooliganism. Hooliganism at Republic of Serbia's sports events, as well as at the events in the countries of the SFR Yugoslavia, has its specifics compared to other countries. That is mostly related to war and ethnic conflicts' heritage. In Serbia, hooliganism problem escalated in the last three decades. Urban areas make spatial and social center, from which the violence spreads to the wider environment. Lately, rising number of drug clans that operate under the flag of the fans of football and basketball clubs is evident. In these cases, money laundering, reselling of the young, talented athletes, as well as controlling the drug's market is also evident. Fan club's violence and hooliganism at sports events is a problem that is very complex and it is impossible to control and solve this problem at sport's forums. Safety endangerment and endangerment of the personal, as well as the property's safety by this kind of violence at sports events requires from the state's institutions and whole society wholesome, adequate and timely response, with coordination and cooperation with private security services and others engaged from private security sector. Also, it is necessary to implement the national legal framework, as well as the implementation of the UEFA's guidelines, related to suppressing racism and xenophobia at sports events. Different measures that are carried out by police should be the last resort and demonstration of the power of the endangered state, that are used only when other, less repressive ways cannot defend the protected values.
\end{abstract}

Key words: fan clubs, safety, violence, sports events, Republic of Serbia 


\section{Introduction}

According to some interpretations, sport's violence should be seen as the relict of ancient rituals or wars, as the groundbreaking events in the development of the certain social community. In that context, it is noted that sports competitions in the antique period represented a period of calmness or a break in between war fights, and maybe even an alternative way of fighting the war. Winning the sport's competition, in certain way, manifested as the dominance of a city or state over rivals. From that period of time, there are evidences of non-sporting behavior of the viewers, of damaging the facilities where the competitions were held, of riots and fights of the opposing fans (Bodin and Associates, 2007).

Two Millennia later, sport became global urban phenomena, considering the fact that very few places on planet stayed outside this area of globalization. Regardless of states' development differences, life standards and free time that average individual has, general characteristic is that bigger and more modern sports facilities are being built, and there is an online global media coverage and broadcast of the most important sports events (Frank and Steets, 2010).

An indispensable condition of sports' competition is that these events and athletes taking part in them are followed by viewers who support them. Their attitude towards the competition has meaningful impact on the competition, as well as on the final results of the competition. It is kind of a division of roles, where the audience is connected with the actors of sports' fight, connected with some, usually temporary, interest. During this kind of interaction, individuals are relatively anonymous, most commonly passive, because they interact only as viewers (Hughson, 2013). Viewers themselves differ based on their reactions at sports events they attend. Also, their reactions depend on the nature of the competition, which means that football audience is, for example, much different from the audience that attends the ice-skating competitions, sailing competitions and similar ones (Young, 2013).

Social function of modern sports has been changed quite much compared to their antique roots, since today's sports events have very important role in controlling the violence, suppressing impulsive urges and setting certain standards for individuals' behavior. On the other hand, sports events represent the part where the behavior that is not the usual behavior and it deviates from the norms is tolerated to certain extent. Also, adrenalin rush that attending to sports events brings, also satisfies the need for thrill (Kuvačić, 1979).

Sports fan or rooter is loyal to a certain sport club/community or national team and it makes him differs from sports' audience. With their active support to the club they root for, fans help, indirectly, the club to achieve its goals, interests and ambitions, all the while they consider the club's success as their won as well. For them, it is common to develop a fans' group, made from individuals with common goals that do their part in accordance with defined internal rules and values. Every fan group has its structure inside which individuals take their different ranks (Frosdick and Marsch, 2005).

What is considered today the violence at sports events, has been around since mid twentieth century, when, because of the science and technology development, broadcasts of sports events became globally available and sports became commercialized. In these new circumstanc- 
es, sport became the tool of different authorities that used media and sport to make stronger impact on their citizens. This is especially characteristic for authoritative regimes. On the other hand, uncontrolled commercializing of the sports had for consequence the appearance of different types of extremism and criminal activities, related to sport (Milenković and Todorić, 2011).

\section{History of violence at sports events}

Different types of fall outs and indecent behavior of the audience and participants became traditional part of the sports events involving group sports, especially when it comes to football. Ever since the beginning of that game (13 ${ }^{\text {th }}$ century, England), violence was its part. Aggressive, asocial and delinquent behavior by fans, at the end of the $19^{\text {th }}$ century was marked as "hooliganism". This term comes from the last name of the Irish family Hooligan, whose members were famous for causing fights and riots at sports games. Hooligan's behavior is defined as rude, useless, aimless action, followed by obvious expressing contempt towards individuals or whole society, behavior that violates public order, insultingly offends citizens and all other similar acts that violate public order and peace. Even though $19^{\text {th }}$ century brought strict rules of the game and elements of chivalry and fair play that are closest to the modern football playing, it is considered that the only period in British history that wasn't marked by riots and violence at football games was the period during WWII (Elias and Dunning, 1986).

During 60's, escalation of the hooliganism happened in England, during period of time when football games were broadcasted and workers accepted the football as their "own". This term became an everyday one in the media when it was necessary to name the participants that caused riots at games, whose initiators were fan group leaders, but also for the participants that caused organized violence and fights of opposed gangs, so called 'firms', on the streets of British cities (Cashmore, Cleland, 2014). Important role in the genesis of this violent counterculture had the movement called "Skinheads", which emerged in Great Britain in the late fifties of the twentieth century. This movement's followers, which mostly came from working class, shaved their heads and showed violence as their way of proving themselves. At the beginning of the eighties, most of skinheads joined far-right political party - Greater Britain Movement and National Front. This caused not only violence escalating, but also spreading the extreme ideology of the far-right parties among groups of the young football supporters in England. In racism and xenophobia they found the vent for their own frustrations (Cawtorne, 2012).

Football supporters' hooliganism first spread in England. It reached its peak on European soil during seventies and eighties. Kind of a turning point were two tragedies that happened on the sports fields. First one happened during the European Cup final match between Liverpool and Juventus F.C., at the Heysel Stadium, Brussels, on $29^{\text {th }}$ of May, 1985. 39 Juventus supporters died and more than 400 of them were injured in the confrontation. Tragedy happened when supporters of Liverpool breached the fence and pressed Juventus supporters against the three meter high wall that ended up collapsing. Most were killed after the wall collapsing and others died from knife and stone fights or got run over by people escaping from the chaos that arose after wall collapsing. After this tragedy, that marked Liverpool's supporters as the main respon- 
sible offenders, British embassy in Italy was attacked few times. British Prime Minister at that moment, Mrs. Margaret Thatcher, took Britain's blame and sent apologies to Italian and Belgium governments. English clubs were banned from UEFA playing in Euro Cups for 5 years (Hopkins, Treadwell, 2014). Four years later, on April 15th 1989 , similar tragedy occurred, where 96 people were killed during the stampede that happened after the fence was breached and conflicts with the police. This happened during the FA Cup semi-final match between Liverpool and Nottingham Forest, at Hillsborough Stadium in Sheffield, England (Armstrong, 1998).

After Heysel and Hillsborough tragedies, British authorities started taking strict legal measures that caused the hooliganism rate's radical decline in this country. More serious incidents at stadiums in England today are considered past and number of people arrested because of this decreases year after year, all because of the strict legal actions by British legislation. Some of those mean large number of convicted hooligans being legally banned from attending the matches that are being held in the country or abroad (Cox and Associates, 2002).

\section{Suppressing hooliganism internationally}

\subsection{Foreign experiences in suppressing the violence at sports events}

Comparison of experience of Great Britain, Italy, Germany, Holland and other countries that during second half of twentieth century especially had issue with hooliganism at sports events, shows that only by careful planning and systematic actions from each and every social participant, as well as by energetic and comprehensive measures, satisfactory results can be reached, when it comes to suppressing hooliganism (Zirin, 2010).

After the disaster at Heysel Stadium, Brussels, 1985, British Parliament passed a law on fighting against hooliganism that contained strict penalty regulations. Apart from this, this act made it obligatory to install cameras at every stadium, in order to be able to record and identify misbehaving participants. Also, regulations of this law recommend that for easier law offenses, case will be taken to a judge for violations, on site. For a fan entering the sport's field, law recommends the jail time, five months to two years' time. In case public order and peace had been disturbed, jail time raises to seven years. Also, offender will be banned from attending sports events, six month to a year, and he is obliged to report to police station and stay there during the match. There is also Football Intelligence Section, specialized operative police unit that is part of the National Criminal Intelligence Service (NCIS). Its main task is to monitor the problem of hooliganism (0'Neill, 2005).

In Italy, law regulations recommend that using of pyrotechnics and throwing them and other objects on the field

qualifies as a violation of the law, for which the jail time goes from three month to three years. For causing riots inside the sport's facility, offender will get house arrest during sports events. Clubs that enable entrance for the offenders, that are being legally prosecuted or are fined, will lose financial aid from the state's funds for three years.

Suppressing hooliganism at sports events in Germany, Belgium, Holland and Scandinavian countries is usually done through investments or so-called "fans projects", with national spe- 
cifics of each country. For example, in Germany goal is to work on better communication and cooperation between fans, police services and clubs (Tsoukala, 2009). Holland tries to resocialize hooligans after their jail time. In this country, at the end of the eighties, coordinators were locally set, in order to contact potential offenders and organize different social activities for young fan. Focus was more on prevention than repression, so the so-called "career hooligans" were not affected by measures against violence, since this type of hooligans consider the hooliganism as a part of collective identity and do not want to give it up. Certain similarities with Holland, when it comes to suppressing violence, exist in Belgium as well, focusing on young fans, with the goal to offer alternatives to hooliganism (Dunning, 2013).

With preventive, repressive and other measures, in last 30 years, in Great Britain and other West European countries, hooliganism has been largely suppressed and violence at sports events has been more under control. In the meantime, this phenomena spread to the post-socialist countries, to West Balkan countries, Africa's and Latin America's poverty areas. This made it hard for national authorities to set the adequate normative legal and organizational framework, that would enable suppressing and preventing violence at sports events (Cleland, 2015).

\subsection{International tools for preventing and suppressing the hooliganism 3.2.1. European Convention on Spectator's violence and misbehavior at sports events and in particular at football matches}

European Convention on Spectator's violence and misbehavior at sports events and in particular at football matches entered into force on 19th of August, 1985, shortly after the Heysel disaster in Brussels. All the states, that signed and ratified the Convention, engaged in taking concrete measures form Convention's implementation and to implement its measures to also other events related to other sports, where there is a justified assumption that it could come to spectator's violence and misbehavior, taking into consideration those sports and sports' events specifics. All the states that signed the Convention are obliged to coordinate political measures and government's authorities actions, as well as the other public services' actions, that are relevant in cases of hooliganism at sports events, by forming the relevant coordinating bodies, if there is a posibility to do so (Tsoukala and Associates, 2016).

Lately Convention's Standing Committee (T-RV) made more recommendations on how to implement European Convention on Spectator's violence and misbehavior at sports events and in particular at football matches. Among others, those are recommendations how to standardize control measures that organizers of the football matches, as well as the public services in charge need to take. Also, recommendation how to implement the measures for high risk sports events held in the sports hall, as well as the recommendation on social and educational measures for preventing sport's hooliganism (Recommendation, 2003), supressing racism, xenophobia and other intolerance in sport (Recommendation, 2001) etc. 


\subsubsection{International sports associations' acts}

Regulations and acts made by international sports associations are becoming more important source of international law for sports competitions and for suppressing violence and misbehavior at sports events in urban areas (Hoolihan, 2014). Among these so-called autonomous international laws for the sport's issues (violence and misbehavior at sports events), most important are the general legal acts made by Federation Internationale de Football Association - FIFA, founded 1904, with headquarters in Zurich, and Union of European Footoball Associations-UEFA, also known as The Union of European Footoball Associations.

In the past years, Football Association of Serbia was fined by UEFA and FIFA more than once, because of the riots, violent behavior and hooliganism, especially refering to football clubs "Partizan" and "Red Star". Those were high fines and they were also banned from playing international matches with the spectators or outside the Belgrade area

When it comes to fines or being banned to play a game in certain sports facilities, which are made by regulations of UEFA's Disciplinary Body, these measures have repressive and preventive character. They are repressive for the organizer of the match (football association, football club), who is fined for not taking measures or inadequate implementing of measures that would prevent hooliganism and misbehavior of spectators, during preparations and during the match. Their preventive effect is that it encourages the football association and football clubs to organize events in a more adequate way and also to have better and closer cooperation with club's supporters, private security services and police services, in order to suppress hooliganism, violence and misbehavior at football matches more efficiently (Frosdick and Marsch, 2005).

\subsection{Issues and limitations in international fight against sport's hooliganism 3.3.1. Issues in sport's hooliganism prevention}

The most important result of the international conventions and recommendations, international sports associations' acts, regional and national regulations is setting up the Institute for surveillance of the spectators at sports events.

This has preventive effect, because it includes sports fans' and fans' groups education. On the other hand, checking and surveillance measures at the same time have discouraging effect on offenders. However, to implement preventive strategies comes with lots of issues, because there is a big gap between recommended measures against hooliganism and European standards concerning, among others, freedom of movement (Bodin and Robène, 2007).

Implementing the European Convention on Spectator's violence and misbehavior at sports events ' recommendations for prevention against sports hooliganism and other relevant international acts is not always easily done because of their inadequate equalization and standards, so their effect depends on engagement of sports associations and national bodies. When it comes to sports' clubs, preventive measures' success depends on their leader's willingness to cooperate and on their toughness/favoritism towards their club's fans. This is an issue for clubs, because the acceptance of preventive and common measures against hooliganism would mean acceptance of moral and material responsibility for actions of their fans. Therefore many clubs 
try to make a deal with fans, by sponsoring them and tolerating their misbehavior, or simply engaging private security services at sports events as a preventive measure against hooliganism. Another obstacle is financial interest, because in case of hooliganism happening outside the sports arena, it no longer makes it sport's issue, but rather violation of public order and peace, therefore the organizers of the ports events are not financially liable. These interests are closely connected to essence of the professional sport- the incomes from commercials, media sponsoring and selling the players. Clubs no longer have the need for large number of fans buying the ticket, which used to be the club's main financing source (James, 2017).

\subsubsection{Limitations in implementing the repressive measures}

Repressive acting against hooliganism and misbehavior of the spectators' at sports events consists of four types of measures that have been adopted by most European countries (Tsoukala and Associates, 2016): security measures (separating the opposing fans' groups, police security, making sure that guest teams are safe, security ring around the sport's facility, security ring on and around sport's field, partial and complete check of the suspicious spectators, different types of check for illegal objects at the stadiums' entrances), surveillance measures (installing the video surveillance at stadiums, placing the police forces between the fans' groups on stands), gathering the information (exchanging the relevant information between engaged police services and sports clubs about the expecting number of the spectators at sports events, as well as the ways of the travelling of the organized fans' groups).

Implementation of these repressive measures is followed by different issues and difficulties. In some European countries, for example France, thorough check of a person is legally determined by regulations that determine the police authorization with arrest warrant. Partial check at entrances is most of the time impossible to do, mostly because of the large number of the spectators at sports events, which come just before the game. Setting the video surveillance system around and inside the sport's facility is also controversial. Although the role of these systems is to prevent and suppress the incidents and to identify hooligans, installing them is an issue for violating the privacy of the people who live nearby. In some states that have more detailed law regulations concerning this question, there is an additional issue of the timeframe for saving the video files from the surveillance cameras. In most European countries, spectators cannot be filmed, unless there is a notice stated clearly on tickets or at the sport's facility's entrance (Hopkins, Treadwell, 2014).

\section{Hooliganism in Republic of Serbia 4.1. Historical background}

At the end of the eighties and beginning of nineties, in the area of SFRY, hooliganism incidents' characteristics were expressive violence and brutality in fans' group's conflicts, destroying and damaging property and strong nationalistic and chauvinism feelings. During this period, first clashes of hooligans and extremists with police were happening. Since then, entrance control to the sport's facilities has been intensified, followed by thorough spectators' check. It 
became forbidden to bring the objects that can endanger safety inside the facility, fans started being escorted when travelling to games. Also other measures started being implemented. Two incidents from 1990 are characteristic, because of exceeding the frames of violence and hooliganism seen before that. First incident was at "Poljud" stadium, Split, Croatia, when supporters of "Hajduk", during the match "Hajduk-Partizan", publicly burned SFRY's state flag. Second incident happened on 13 th of May, 1990, at "Maksimir" stadium, Zagreb, Croatia, where, during "Dinamo-Red star" match, fans clashed on the stands and on the field. That was broadcasted via media and whole Yugoslavia saw it. These incidents were an overture to SFRY's falling apart and the beginning of the civil war, during which these hooligans' groups actively participated (Hughson and Skillen, 2015).

After the war had ended, in mid-nineties in SFRY, extreme fans' groups were being used for encouraging street violence as means of regimentation of the political structures and public and also sometimes as means of provoking some of the most influential members of the international community. More often they were efficient mechanism for controlling the criminal ways, especially for drug market (Čolović, 2002).

In Republic of Serbia, this hooliganism problem escalated in the last two decades, during which there were disasters with deadly outcomes, cases of larger scale of violation of the public order and piece, bigger incidents at sports games and outside them, with lots of injured spectators, which also meant destroyed and damaged property. Politically inspired public gatherings, which were attended by hooliganism and other extremist, usually turned to violent riots, demolition and destruction (Đurđević, 2010).

\subsection{Forms of hooliganism manifestation in Republic of Serbia}

Most important causes for hooliganism escalation in Republic of Serbia during first decade of the twenty-first century are considered to be: forming of the hooligans' groups and their growing organization, rising level of their aggression, criminal actions, politicization and external manipulation of those groups. Other causes for hooliganism in Serbia and neighboring countries are: economic and social crisis that are suitable for hooliganism, slowly fading away of the general system of values, great ideas' crisis, marginalized status of the youth, unemployment, without perspective, general sports' clubs and associations state they are in (political interference, criminalization, money laundering, fixing the games and betting abuse, irregularities concerning selling the players abroad, non-transparent business, avoiding paying taxes), hooliganism institutionalization through fans' organizations and protective attitude towards fans (Milošević and Milašinović, 2011).

Extreme fans' groups in Serbia do not have solid ideology, except the national chauvinist one, but that does not prevent them from making alliances with similar types of groups in neighboring countries. They claim to also be traditional type of believers, but contradictory is that they value material status very much. These groups have some disoriented participants, but also the ones that believe that their hooliganism is a way of expressing the protest against society and that it is the legit personal choice (Savković and Đorđević, 2010). 
Rising influence of the drug groups that work under the flag of fans' groups of the biggest domestic clubs is also evident. It is no wonder that there is reasonable government's interest in biggest football and basketball clubs, in which money laundering, game fixing, reselling talented, young players, control of criminal groups and drug market is present for years.

It is for certain that sports events organized by those clubs are sometimes just cover for different types of criminal activities (Savković, 2010).

Fans' groups used their participating position in taking down the regime of Slobodan Milošević after 2000. From 2001 to 2008, biggest expansion of the hooliganism movement at stadiums in Serbia happened. Size and level of organization grew in almost all fans' groups and state's benevolence, especially during Zoran Đinđić and Vojislav Koštunica's government, those groups were let to clash, often with tragic outcome. During this period, extreme right organizations ("Obraz', SNP "Naši', "1389") and neo-Nazi groups recruited activists at stadiums. That was fully shown at "Kosovo is Serbia" demonstrations, organized in Belgrade, on 21 $1^{\text {st }}$ of February 2008, when Kosovo's independence was declared, one-sided. Considering this fact, period from 2008 to 2010 generally was the time of the most intense cooperation between extremists' organizations and hooligans (Jakšić, 2012).

After 2002, situation in hooligan movement and extreme right organizations in Serbia had significantly changed.

Members of these groups vanished from the streets, and stadiums were under control. This movement in Serbia is significantly in stagnation mode, for which there are many reasons, but the most important one is the state's decision that in any way possible gains control over fans, which includes some types of bribing their leaders, so that they cooperate with police and help keep in control other fans' groups (Stanković, 2013).

\subsection{Hooliganism in Serbia from the aspect of criminal law and law enforcement}

By passing the Law on preventing the violence and misbehavior at sports events, in 2003, in which is stated criminal act of hooliganism at sports events, Republic of Serbia fulfilled its obligation that was stated in Law on the ratification of the European Convention on Spectator's violence and misbehavior at sports events and in particular at football matches. This Convention was ratified by SFRY in 1990.

Article 17 of this Law recommends measures that Ministry of Interior of Republic of Serbia can implement in order to prevent hooliganism and extremism. Police has authority to implement these measures: to order fans' groups routes and direction of movement when coming/ leaving from the sport's facility; to order the organizer to remove the facility's shortcomings or organizing oversights, especially the ones noticed during the sports event that can significantly endanger safety of participants; to prevent arrival to the place of the sports event or to forbid entry to the sports event, also to remove the person from the sports event if their behavior is likely to become violent and indecent.

Engagement of police forces in Republic of Serbia, for safety reasons at sports events and in order to suppress hooliganism, in last three decades is characterized by "high profile" ap- 
proach and strategy, that, when implemented on tactical level, is followed by implementation of different police intervention measures. In EU countries, this kind of approach is considered old fashioned and not efficient. Since the nineties, in these countries "low profile" strategy has been used, which means implementing mostly non-intervention police measures on tactical level. Implementing this "low profile" strategy on tactical level is not only more efficient and humane that "high profile" strategy, but it is also, considering economic criteria, more efficient and successful. However, "low profile" strategy is more complex and more demanding, because it implies developed partnership of police and local and wider community (with organizer's private security services, private security agencies, sports clubs and associations, legislative institutions, media, non-government organizations). On the other hand, effects that are achieved by using this strategy are also like that, so they justify its acceptance and implementation (Milojević and Associates, 2013).

\section{Conclusion}

This kind of extremism does not appear by accident, it reflects certain society's state and represents reaction to the existing one, as well as the upcoming crisis in the state and its surroundings. Reasons for the extreme type of hooliganism can be different, including national intolerance, religious intolerance, political intolerance, racism and similar.

Young people gathering around clubs they support and their conflicts with other fans' groups and conflicts with the law is the occurrence that is, from the beginning of seventies, regularly and massively present in the parts of the world where football attracted people from lower social positions and where the violence amongst people was present before as well-from Brazil to Argentine, through Europe, all the way to Africa. Vandalism that often goes hand in hand with this kind of violence represents the part of the problem that states still try to solve in any way possible.

During seventies, throughout Europe, first campaigns against football hooliganism, followed by draconic fines for misbehavior at sport events were started. At the same time, first laws that dealt with "antisocial behavior" and organized youth delinquency that became big problem for states, were being passed.

Compared to other countries, fans' violence at sports events in Republic of Serbia and countries of SFRY has its characteristics, which are mostly related to war and ethnic conflicts' heritage. It's about the process that had started at the end of eighties, when violence was transferred from sports' fields to political grounds. But, also before this, during Yugoslavian communism regime, sports' playgrounds represented some kind of vents, where everything that could not be said in public, because of the authoritative system, was being said there, usually anonymously from the crowd.

International attempts to suppress hooliganism are opposite to general trend of commercializing professional sports' competitions, especially football matches. It's less about the sport and spectacle, but more about promoting certain number of international companies and about media popularity, as well as the social presenting of the people that lead those kind of com- 
petitions. For these reasons, internationally the goal is more to make sports hooliganism less visible, rather than to suppressed it and prevented it. Example for this are sports fields in Great Britain, where supporters are being selected by high-priced tickets, by removing the stands and by draconic fines for derailing from behavior that is stated to be accepted at stadiums.

From Great Britain's experience, it is noticeable that hooliganism can be disabled with suitable legal framework, as well as the efficient and coordinated actions of legislative, executive and judicial institutions. On the other hand, for most countries that deal with expansion of violence at sports events, which mainly refers to countries in transition, main problem is not non-existing, but inadequate implementation or non-implementation of the law, because of the poor work of institutions' system on national level, but also because of the connections fans' groups have with political core and with organized criminal.

Endangerment of safety and personal property's safety by fan's violence at sports events requires from all state's institutions and society wholesome, adequate and timely response. Different measures taken by police should be ultimate means only. Power demonstration of endangered country is done only when other, less repressive ways cannot defend protected values. Realistic evaluation of the endangerment from hooliganism in concrete situation should be a starting point for formulating the right answer, which goes with preventive strategy and tactics, preventing and suppressing destructive behavior and violent acts of hooligans at sports events.

Keeping public order and peace, security protection of spectators and suppression of violence at sports events is complex task, which can often be inconsistent with international norms concerning human rights. Practically, it can happen that police and private security services' actions protect general interest, which means strict appliance of the laws and regulations, also respecting the celebrating atmosphere that exists at every sports event, but also duty to take care of the urban surroundings of the sports facility. Often those interests are conflicted. Citizens that live nearby stadiums are often exposed to different kind of limitations, disturbance and inconveniences, like traffic jams when spectators start to leave after sports event. To keep public order and peace in the city center requires additional tasks, firstly concerning the safety of citizens on the streets, then directing fans' groups towards or from the stadium. It often happens that advantage is given to public interest, so sometimes entrance to stadium is allowed to potential hooligans, after which they are monitored. This is considered more acceptable than causing the riots just before the beginning of sports event. This way, opportunism has advantage over strict law enforcement.

\section{References}

1. Armstrong, G. (1998). Football Hooligans - Knowing the Score. Oxford UK: Berg Publishers.

2. Bodin D. et. al. (2007) Sport i nasilje u Europi. Zagreb: Knjiga trgovina d.o.o.

3. Cashmore E. Cleland J. (2014) Football's Dark Side - Corruption, Homophobia, Violence and Racism in the Beautiful Game. Basingstoke UK: Palgrave Macmillan.

4. Cawthorne, N. (2012). Football Hooligans, London: Little, Brown Book Group. 
5. Cleland, J. (2015) A Sociology of Football in a Global Context. New York: Routledge.

6. Committee of Ministers. (2001) Recommendation Rec (2001) 6 of the Committee of Ministers to member states on the prevention of racism, xenophobia and racial intolerance in sport. Strasbourg: Council of Europe.

7. Cox R. et. al. (2002) Encyclopedia of British Football. London: Frank Cass.

8. Colović, I. (2002) The Politics of Symbol in Serbia. London: Hurst \& Company.

9. Dunning, E. (2013). Sport Matters - Sociological Studies of Sport, Violence and Civilization. London: Routledge.

10. Đurđević, N. (2010) „Krivična odgovornost za nasilje i nedolično ponašanje na sportskim priredbama u Republici Srbiji“. In: Zbornik radova Pravnog fakulteta u Splitu, Vol. 47, No. 2, str. 285-308.

11. Elias N. Dunning E. (1986) Quest for Excitement - Sport and Leisure in the Civilizing Process. Oxford UK: Blackwell.

12. Frank S. Steets S. (2010) Stadium Worlds - Football, Space and the Built Environment. Abingdon UK: Routledge.

13. Frosdick S. Marsch P. (2005) Football Hooliganism. Cullompton UK: Wilian Publishing.

14. Hoolihan, B. (2014). The Government and Politics of Sport. New York: Routledge.

15. Hopkins M. Treadwell J. (2014). Football Hooliganism, Fan Behaviour and Crime - Contemporary Issues. Basingstoke UK: Palgrave Macmillan.

16. Hughson J. Skillen F. (2015) Football in Southeastern Europe - From Ethnic Homogenization to Reconciliation. New York: Routledge.

17. Hughson, J. (2013). The Making of Sporting Cultures. Abingdon UK: Routledge.

18. Јакшић, Б. (2012) Овде и тамо - године колективне мигрене. Београд: Завод за уџбенике.

19. James, M. (2017) Sports Law. London: Red Globe Press.

20. Kuvačić, I. (1979) Obilje i nasilje. Zagreb: Naprijed.

21. Миленковић Д. Тодорић В. (2011) Правни оквир спречавања насиља и недоличног понашања на спортским приредбама. Београд: Центар за нову политику.

22. Милојевић C. et. al. (2013) Млади и хулиганизам на спортским приредбама. Београд: Мисија ОЕБС у Србији.

23. Милошевић Г. Милашиновић С. (2011) "Насиље навијачких група у Србији и криминалитет малолетника". In: Теме, Vol. 35, №. 2, стр. 495-510.

24. O'Neill, M (2005) Policing Football - Social Interaction and Negotiated Disorder. Basingstoke UK: Palgrave Macmillan.

25. Савковић М. Ђорђевић С. (2010) „На путу превенције насиља на спортским приредбама: Предлог регионалног оквира сарадње“. In: Предлог практичне политике. Београд: Београдски центар за безбедносну политику. стр. 7-27.

26. Савковић, М. (2010) "Контекст и импликације фудбалског насиља у Србији“. In: Безбедност Западног Балкана, Vol. 5, №. 18, стр. 91-99.

27. Standing Committee. (2003) Recommendation Rec (2003) 1 of the Standing Committee on the role of social and educational measures in the prevention of violence in sport and handbook on the prevention of violence in sport. Strasbourg: Council of Europe.

28. Станковић, Б. (2013) Инсајдер, моја прича. Београд: Самиздат Б92. 
29. Tsoukala, A. (2009) Football Hooliganism in Europe - Security and Civil Liberties in Balance. Basingstoke UK: Palgrave Macmillan.

30. Tsoukala A. et. al. (2016) Legal Responses to Football "Hooliganism“ in Europe. The Hague NL: T.M.C. Asser Press.

31. Young, K. (2013) Sport, Violence and Sociiety. New York: Routledge.

32. Zirin, D. (2010) Bad Sports - How Owners Are Running the Games We Love. New York: Scribner. 